\title{
Bracketing procedural, distributive and interactional justice with employee career commitment and supervisor commitment
}

\author{
${ }^{1}$ Sobia Raja, ${ }^{2}$ Aneela Abraiz, ${ }^{3}$ Tahira Malik Tabassum, ${ }^{4}$ Muhammad Jawad \\ COMSATS Institute of Information Technology, Wah Cantt.
}

\begin{abstract}
This research study covers the area of human resource management, where Employee commitment to the organization is difficult to retain; researches are being conducted regarding this issue, in this perspective two constructs are selected here under organizational commitment i.e. employee career commitment and supervisor related commitment. In this perspective organizational justices are taken as independent variable, where direct effect of these justices including procedural, distributive and interactional is seen on employee commitment.

Purpose of this study is to explore the role of organizational justice in organizational commitment; main purpose of this study is to relate the procedural, distributive and interactional justice with employee career commitment and supervisor related commitment, how much these justices have effect on overall organizational commitment. So this study has great significance as it could be a major contribution towards the defense sector of Pakistan in analyzing the factors towards the employee commitment.

This research study will be a great contribution in the public sector organization, where it is really difficult to have committed workforce, this study is an attempt to measure that how much is there role of organizational justice in organizational commitment.

Findings of this research study show positive and strong correlation among the model variables. That is a clear identification of the fact that perceived fairness in distributive, procedural and interactional justice's leads towards high level of commitment.
\end{abstract}

Keywords: Organizational justice, procedural justice, distributive justice, interactional justice, organizational commitment, supervisor related commitment, career commitment

\section{Introduction}

No one can deny the importance of justice in organizations, so in this context this research study will focus on the linkage of organizational justices with organizational commitment. Organization justice deals with procedural, distributive and interaction justice. To check the role of these justices on organizational commitment will be the main focused area. This study will address management issues regarding employee career commitment and supervisor related commitment that how justices can play vital role towards the organizational commitment.

In organizations, justices play important role while taking decisions regarding job roles allocations or while taking other necessary decisions regarding promotions or other benefits etc. in this perspective a lot of work has been done for the years, procedural justice deals with the fairness in procedures in the organization, this fairness is while taking decisions in the organizations.

Though a lot of work has been done in this in this area, but still I believe that issues that will be highlighted in this research study could be beneficial in Pakistani organizational cultural perspective. Justices not only deals with public sector but also with private sector organizations. This study will be a great contribution towards the overall organizational commitment. In Pakistani cultural it is really difficult to bring change because of some sort of rigidity.

This study will contribute to bracketing these justices in relation to career commitment and supervisor commitment. Pragmatic research on procedural justice has been done. in the beginning it was of common thinking that only procedural and distributive justices comes under the head of organizational justice but in 1980s it was revealed that interactional justice is also the type of organizational justice.

Though Pakistani organizational culture is improving day by day and research and development has been accepted by many of the organization. Many of the organization have to face issues related to employee commitment and supervisor related commitment, this research study is an attempt to explore the some hidden aspect regarding commitment through procedural, distributive and organizational justice. Justices that are followed in the organization really have great impact on the commitments of employee and supervisor as well. Main objective of this research study is

$\checkmark$ To examine the role of justices in organizational commitment

$\checkmark$ To explore the different types of organizational justice (procedural, distributive and interactional justice) and their relationship with career commitment and supervisory related commitment. 
$\checkmark \quad$ To aid managers in proper dealing with commitment related issues in organization.

$\checkmark$ To explore the concept of justices in organizational commitment

The study will deal with the following research queries:

1. What is the relationship between organizational justices with organizational commitment?

2. What is the relationship between procedural justice and supervisor related commitment?

3. What is the relationship between procedural justice and employee career commitment?

4. What is the relationship between distributive justice and supervisor related commitment?

5. What is the relationship between distributive justice and employee career commitment?

6. What is the relationship between interactional justice and supervisor related commitment?

7. What is the relationship between interactional justice and employee career commitment?

\section{Organizational justice:}

\section{Literature Review:}

Organizational justice has been emerged as the hottest topic on the discussion boards for many years in Human resource management, organizational behavior and organizational psychology(Cropanzano, 1997);(Colquitt, 2001); (Greenberg.J, 1990). Different type of justices has been taken as the variables for a longer period of time (Deutsch.M, 1975); (Adams, 1965); Organizational justice basically explains the fairness perceptions of individuals or of group and then their behavior can be observed according the treatment they receive from their organization (Deutsch.M, 1975; k., 1993)

(Greenberg.J, 1990)reviewed and predicted that organizational justice would be at the top in organizational behaviors, the reason behind is the strong relation of organizational justice variables to the organizational outcomes as (Folger R.\& Konovsky, 1989)realized that organizational justice perceptions were strongly related to organizational commitment and supervisory related commitment.

Researches on Fairness perceptions shown great consequences on the work place (Colquitt, 2001);(CohenCharash, 2001), like organizational commitment (Masterson, 2000) and job satisfaction (Alexander, 1987)

In the beginning organizational justice was considered in only two dimensions, procedural justice and distributive justice; procedural justice is about the perceived fairness of the means that leads to determine the outcomes, as it shows the concerns about consistency, impartiality rationality and employee participation(Cropanzano, 1997);(Folger R.\& Konovsky, 1989), (Greenberg.J, 1990) he found that procedural justice and distributive justices are linked to employee work related behaviors and attitudes. In this perspective (Folger R.\& Konovsky, 1989)put their contribution by reporting that distributive justice is related to pay satisfaction whereas procedural justice is strongly related to organizational commitment and supervisor related commitment.

In organizational justice fair treatments have great considerations on employee attitudes at workplace including employee commitment and job satisfaction (Colquitt, 2001)

\section{Procedural justice:}

The development of procedural justice theory came into existence when (Thibaut, 1975)research on different disputes and individuals reactions towards them, in this judgments was concerned with means by which decisions are made. In this perspective of procedural justice, researchers offered different operationalization typologies ((Thibaut, 1975); (Leventhal, 1980)In this fairness of decisions making practices and policies was the main concern for the individuals.

\section{Distributive justice:}

Distributive justice is linked with the outcomes an individual receives in literature distributive justice was taken in concern to pay injustices. (Walster, 1978); (Adams, 1965). Distributive justice is when there is a congruency of actual and expected outcomes. People mostly expect on the basis of their experience, effort and ability. (Adams, 1965)and (Walster, 1978)took the social exchange approach, in which he mentioned that mostly individuals are seek towards distributive justice, because they think fairness will be favorable to their outcomes. Empirical work has been done in addition to distribution rules that demonstrates, empirical work on choices of distribution rules demonstrates that careful actors benefits materially (Messick, 1979)

\section{Interactional justice}

Third dimension that is related to organizational justice is interactional justice. Many researches have highlighted its importance as in the decision making process. In corporate recruitment setting(Bies \& Moag, 1986)) On the basis of a qualitative study of treatment expectations in a corporate recruitment setting, four criteria regarding interpersonal treatment were identified by (Bies \& Moag, 1986)They highlighted that fairness of this interpersonal treatment depends on the extent to which decision making authorities are trustworthy and communicate decisions accordingly. Interactional justice is further evaluated on the basis of interpersonal and 
informational aspects of decision maker's behavior that how well he communicates it to the others (Greenberg, 1993)

\section{Organizational commitment and Justices;}

Over the year this has been common assumptions that, employees who have a sense of belongingness and attachment to their organization, they mostly do work harder than the others. This concept fosters employee's organizational commitment and identification as well.

(Cohen.A, 1991);(Mathieu JE, 1990);(Allen NJ, 1996); (Mowday RT, 1982);(Organ DW, 1995); (Randall, 1990)(Martin, 1996); (McFarlin, 1992)emphasized that procedural and distributive justice are significant predictors of work place behaviors and attitudes., role of procedural justice is more in organizational commitment (Folger R.\& Konovsky, 1989);(McFarlin, 1992); (Martin, 1996)

\section{Supervisory commitment;}

Though a lot of work has been done on organizational commitment but it was taken in a single dimension. Work of (A. E. Reichers, 1985)(A. E Reichers, 1986)proposed multiple models for organizational commitment; he further added that employee commitment can be towards the top authorities, it could be towards the supervisor or other top management level. In this perspective Studies of(Becker, 1996);(Hunt, 1994) investigated a strong relationship of organizational commitment with constituency commitment. I.e. supervisor, coworkers and top management

Previous studies on organizational commitment showed a positive relationship to employee outcomes. Including job satisfaction(Bateman, 1984)and attendance (Mathieu JE, 1990) job performance (Meyer, Allen, \& Smith, 1993) . (A. E. Reichers, 1985), who has great contribution in highlighting the other forms of commitment, noted that combination of commitments might be the best. She emphasized that employee have to face several commitments while performing the job, so it is important to understand the organizational commitment along with other commitments.

\section{Employee career commitment;}

(Mathieu JE, 1990)pointed about the different career stages in employee overall organizational commitment, there are several studies that highlighted that employee organizational commitment and outcomes are moderated by employee career stage. These theories (Super, Zelkowitz, \& A., 1981)and other organizational commitment models explained by (Mowday RT, 1982)and(A. E. Reichers, 1985).

Though a huge literature is available on these justices, a lot of work has done on this topic. Organizational commitment has also been the hottest issue on discussion board for the years. Variables took in the dimensions of pay raise, promotion, decision making. While collecting data on these variables, literature didn't answer about an appropriate linkage of these variables, in many researches procedural justice and distributive justice is taken together but there is not any direct relation shown among these justice and organizational commitment, organizational commitment is taken as moderating variable. Literature didn't provide enough relationship among procedural, distributive justice, interactional justice with organizational commitment i.e. further dealt with supervisor related commitment and career commitment.

\section{Methodology;Theoretical Model:}

In this model three different forms of organizational justices' i.e. procedural, distributive and interactional justice taken as independent variable. And supervisory commitment and career Commitment is taken as dependent variables.

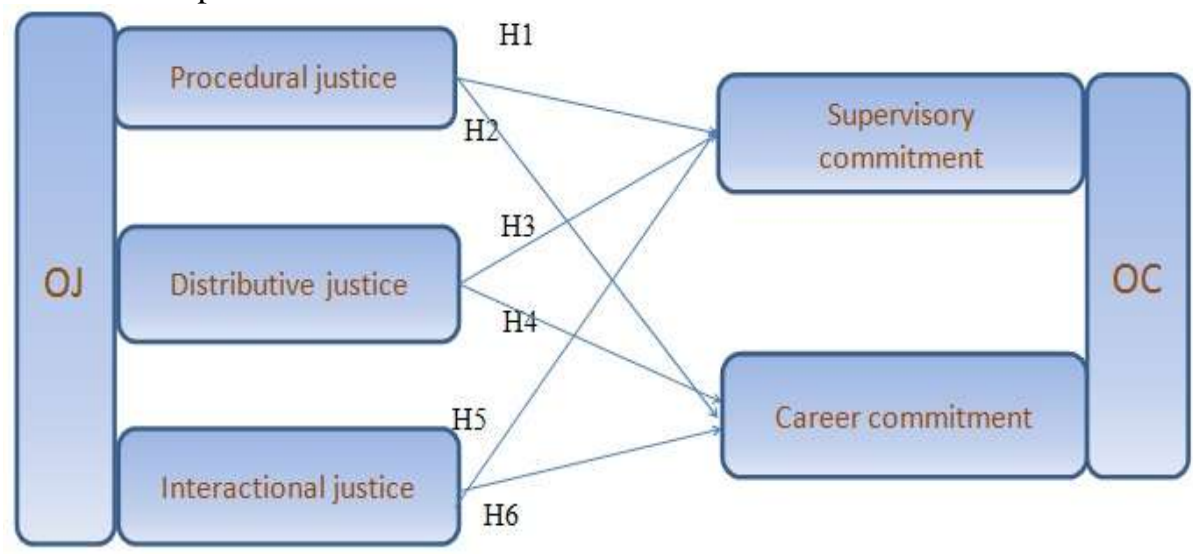

Fig. 1 Relationship of organizational justice with organizational commitment 
In this theoretical model the main purpose is to check the relationship between the justices with organizational commitment, though a lot of literature is available regarding justices and organizational commitments, but in literature organizational commitment collectively in the form of supervisory commitment and career commitment but is never directly explained with justices. So in this model the main inclination is towards the linkage of organizational justice with organizational commitment regarding supervisory commitment and career commitment.In a recent research paper "Linking employees' justice perceptions to organizational commitment and intention to leave: The mediating role of perceived organizational support" (Loi Raymond, Hang, \& FoleySharon, 2006)they found significant positive relationship between Procedural and distributive justice to organizational commitment $(r=.48$ and.42)

In another research paper "Procedural Justice, Distributive Justice: How Experiences with Downsizing Condition Their Impact on Organizational Commitment" by (Clay, A., \& Paul, 2005)worked on justices and organizational commitment and found both procedural and distributive justice as significant predictors towards the organizational commitment.

From literature it is quite obvious that perceived fairness in decisions, job responsibilities and work load leads towards the strong organizational commitment. It creates the strong sense of identification and affiliation toward the overall organization including commitment to supervisor as well as towards the career. It is quite obvious when employee are dealt fairly it will generate a strong feeling of obligation towards their organization and they work in more committed way. When fair procedures for job decisions along with appropriate allocation of resources and fair communication of decisions results in high commitment.

\section{Procedural justice:}

\section{Variable Explanation;}

A lot of research studies have explained procedural justice in different dimensions including workplace behaviors and attitudes also an extent to which employee have involvement in decisions, voice and choice they have. In a study Linking employees' justice perceptions to organizational commitment and intention to leave: The mediating role of perceived organizational support of(Loi Raymond, et al., 2006), they applied regression analysis on 514 practicing solicitor in Hong Kong, their results showed that procedural and distributive justice are positively linked with organizational commitment.

There is another research study on "Examining the Construct of Organizational Justice: A Meta-Analytic Evaluation of Relations with Work Attitudes and Behaviors by(Chockalingam \& S., 2002)worked on procedural justice and check relationship of it on organizational commitment along with job satisfaction and productivity.

Research study on "Procedural Justice, Strategic Decision Making, and the Knowledge Economy" by(Chan \& Renee, 1998), find out the relation between procedural justice in decision making. In this paper they discussed about that when employee feel that decision making process is fair they display high level of commitment.

\section{Distributive justice:}

In distributive justice perspective studies have been done in following dimensions including allocation of rewards and recognition.

A research study "Procedural Justice, Distributive Justice: How Experiences with Downsizing Condition Their Impact on Organizational Commitment" by (Clay, et al., 2005)also explore the impact of procedural and distributive justice on organizational justice,they found significant positive relationship between them.

In a research study of (Fields, Pang, \& Chiu, 2000)in "Distributive and procedural justice as predictors of employee outcomes in Hong Kong" found a positive relationship of distributive justice with supervisory commitment.

\section{Interactional justice:}

(Bies \& Moag, 1986)worked on the different aspect of interactional justice, and explained that it depends on the trust of supervisor that they do in communicating the decision, that leads towards the high commitment in employees.

\section{Supervisory commitment:}

Though a lot of work has been done on organizational commitment but it was taken in a single dimension. Work of(A. E. Reichers, 1985) proposed multiple models for organizational commitment; he further added that employee commitment can be towards the top authorities, it could be towards the supervisor or other top management level. In this perspective Studies of (Becker, 1996); (Hunt, 1994)investigated a strong relationship of organizational commitment with constituency commitment. I.e. supervisor, coworkers and top management 


\section{Employee career commitment;}

(Mathieu JE, 1990)pointed about the different career stages in employee overall organizational commitment, there are several studies that highlighted that employee organizational commitment and outcomes are moderated by employee career stage. These theories (Super, et al., 1981)and other organizational commitment models explained by (Mowday RT, 1982)and(A. E Reichers, 1986).

So this created following evidences towards the following hypothesis so it is hypothesized that

H1: procedural justice is positively related to supervisor commitment

H2: Distributive justice is positively related to supervisor commitment

H3: Interactional justice is positively related to supervisor commitment

H4: Procedural justice is positively related to career commitment

H5: Distributive justice is positively related to career commitment

H6: Interactional justice is positively related to career commitment

Data Collection and sampling:

This study was conducted on the employees of different organizations in defense sector. Sample size consisted of 250; and only 200 got back, as questionnaires were filled from the subjects of different post and of different age group, experience and qualification. Some questionnaires were sent thorough mail and rest of the questionnaires was administered during working hours. Subjects were realized and well informed about the confidentiality issues regarding the information.

\section{Results:}

Data analysis of the data gathered conducted mainly in two steps, first confirmatory factor analysis CFA was conducted in order to check the validity of the instrument. Cumulative values of the questions were satisfactory, all above 0.4. Table 2 shows the overall reliability of the instrument; chronbach's alpha for the questions is 0.885 , while table 3 shows the reliabilities for the individual variables, for supervisor related commitment its .620 and for career commitment it's 0.541 . These are the dependent variables.

While for independent variables including distributive justice, procedural justice and interactional justice its $0.800,0.485$ and 0.671 respectively. Table 4 shows the descriptive analysis, where the values show the mean, median, and std. deviation. Basically it gives information about the variance present. As table shows that there were no missing values and overall variance was quite low.

After descriptive analysis, correlation matrix shows the relationship between justices and organizational commitment. Relationship between supervisors related commitment to distributive justice is .145 that shows weak positive relationship in them. But if we notice then we can observe that supervisor related commitment is significantly related to procedural and interactional justice with the values 0.326 and .431 respectively. The other dependent variable i.e. career commitment showed strong positive correlation with all the three independent variables i.e. with distributive justice it is .615 , for procedural justice its .677 and for interactional justice its value is .593 . So the correlation matrix shows that procedural, distributive and interactional justices are more closely and significantly related to career commitment while it is weekly but positively correlated with supervisor related commitment.

Though literature provide enough support regarding these sort of commitment with justices perceptions, more perceived fairness leads towards high level of organizational commitment.

In order to have regression analysis we can split the model in two halves,one half that explains the justices with supervisor related commitment and other half with career commitment and justices, when apply regression analysis ANOVA table shows the significance of model. While model summary of this regression analysis gives $\mathrm{R}$ square as .537 and adjusted $\mathrm{R}$ square 0.528 , it shows that $52 \%$ model's dependent variable explains the independent variables. While other half of the model that is related to supervisor related commitment's adjusted $\mathrm{R}$ square is .304, it means this variable explains the independent variable 30 percent. Beta value in coefficients shows that it is highly significant in supervisor related commitment. But in career commitment it'ssignificant with distributive justice, procedural justice and supervisor related commitment, But weak with interactional justice. From these results it shows that as results are quite significant so our hypotheses are significantly relate with each other. Higher the perceived fairness higher will be the level of commitment not only at an employee career commitment but also with supervisor related commitment.

\section{Conclusion:}

These researches study basically an attempt to link organizational justices. I.e. distributive, procedural and interactional justice with organizational commitment, in this study organizational commitment is taken in other dimensions other than organizational commitment itself. It was an attempt to explain the effect of collective commitment. Either it's in the form of supervisor related commitment or career commitment. Where ever it would be, it will enhance the level of trust and commitment in the employees. 
This research study satisfies the aims and objectives of this research paper, as its main objective was to show the linkage between justices and organizational commitment in other dimensions of commitment. After conducting this study and significant results of it are the clear indications that the required objectives are achieved properly. If managers start dealing with the subordinates in fair and trustful manner then they can enhance the employee commitment and this will results in overall performance of the organization and increased productivity level. Though it seems easy to say that you need to be fair in all the dealings but sometimes we have to face hidden barrier that creates hurdles in dealing that lowers the overall commitment level of the employee in the organization.

As this research study was conducted on the defense sector, where its common assumption that everything will be fair, so it's an attempt to provide something beneficial to them. So it's important to focus the results, as it shows the strong correlation with each other. Though a lot of literature is available regarding justices and dimensions of organizational commitment but this study is significant because it relates all the three justices with the combination of justices that is supervisor related commitment and career commitment that leads towards the overall organizational commitment.

Both these variable, organizational justice and organizational commitment has long been on the discussion boards, a lot of work has been done on these topics, every day new dimensions and new linkages are explored by the scholars. As if we go to some years back then we will come to know these terms seemed quite anonymous that have become the part of us now. Similarly things go on and on, new and improved ideas or things always take the place of others and so the replacement happens.

\section{Future implications and limitations:}

Though this research study showed the significant results but still there are so many limitation and implications,

$\checkmark \quad$ The first main thing is the sample size that is quite small as it chosen from the organization in vicinity, so it cannot be generalized. Cultural barrier is the major barrier, where we cannot narrate the things as we can in our own culture.

$\checkmark$ Data gathered was from defense sector, other sectors can also be added in it in order to enhance the generalizability.

$\checkmark$ Attitudes towards questionnaire filling is too poor, as people some time show biasness or sometimes they never express what they actually want to say.

$\checkmark \quad$ This study could be helpful for manger as it explores the ways to enhance the commitment level of the employees in the organization.

\section{References:}

[1] Adams, J. S. (1965). Inequity in Social Exchange. Advances in Experimental Social Psychology 2, 99.

[2] Alexander, S., \& Ruderman,M. . (1987). The role of procedural and distributive justice in organizational behavior. Social Justice Research, 1, 177-198.

[3] Allen NJ, M. J. P. (1996). Affective, continuance, and normative commitment to the organization. Journal of Vocational Behavior, 49, 252-276.

[4] Bateman, T. S., \& Strausser, S. . (1984). A longitudinal analysis of the antecedents of organizational commitment Academy of Management Journal 27, 232-244.

[5] Becker, T. E., Billing, R. S., Eveleth, D. M., \& Gilbert, N. L. (1996). Foci and bases of employee commitment: implications for job performance. Academy of Management Journal, 39, 464-482.

[6] Bies, R. J., \& Moag, J. F. (1986). Interactional justice: Communication criteria of fairness. . Research on negotiations in organizations 1, 43-55.

[7] Chan, K. W., \& Renée, M. (1998). Procedural Justice, Strategic Decision Making, and the Knowledge Economy. strategic management journal, 19, 323-338

[8] Chockalingam, V., \& S., O. D. (2002). Examining the Construct of Organizational Justice: A Meta-Analytic Evaluation of Relationswith Work Attitudes and Behaviors. journal of business ethics, 38, 193-203.

[9] Clay, W. J., A., H. K., \& Paul, R. (2005). Procedural Justice, Distributive Justice: How Experiences With Downsizing Condition Their Impact On Organizational Commitment. Social Psychology Quarterly 68, 89-102.

[10] Cohen-Charash, Y., \& Spector,P.E. (2001). The role of justice in organizations: A meta-analysis. Organizational Behavior and Human Decision Processes, 86, 278-321.

[11] Cohen.A. (1991). Career stage as a moderator of the relationships between organizational commitment and its outcomes: a metaanalysis. Journal of Occupational Psychology, 64, 253-268

[12] Colquitt, J. A. C., D.E.Wesson.M.J,Porter,C.O., \& Ng, K.Y. (2001). Justice at the millennium: A meta-analytic review of 25 years of organizational justice research. Journal of Applied Psychology, 86, 278-321.

[13] Cropanzano, R. G., J. (1997). progress in organziational justice:tunneling through the maze,. international review of industria and organizational psychology, 12,317-372.

[14] Deutsch.M. (1975). Equity, equality and need: what determines which value will be used as the basis for distributive justice? Journal of Social Issues 31, 137-149.

[15] Fields, D., Pang, M., \& Chiu, C. (2000). Distributive and Procedural Justice as Predictors of Employee Outcomes in Hong Kong Journal of Organizational Behavior, 21(5), 547-562.

[16] Folger R.\& Konovsky, M. A. (1989). Effects of procedural and distributive justice on reactions to pay raise decisions. Academy of management Journal 32, 115-130.

[17] Greenberg, J. (1993). Stealing in the name of justice: Informational and interpersonal moderators of theft reactions to underpayment inequity Organizatinal Behavior and Human Decision Processes, 54, 81-103. 
[18] Greenberg.J. (1990). organizational justice: Yesterday, today, and tomorrow. Journal of management, 16, 399-432.

[19] Hunt, S. D., \& Morgan, R. M. . (1994). Organizational commitment: one of many commitments or key mediating construct. Academy of Management Journal, 37, 1568-1587.

[20] k., j. (1993). The social context of organizational justice: cultural, inter group and structural effects on justice behaviors and perceptions. In Justice in the Workplace. Human Resource Management, NT, 21-50.

[21] Leventhal, G. (1980). What should be done with equity theory? In K. Gergen, M. Greenberg, \& R. Willis (Eds.), Advances on theory and research

[22] Loi Raymond, Hang, Y. N., \& FoleySharon. (2006). Linking employees' justice perceptions to organizational commitment and intention to leave: The mediating role of perceived

[23] organizational support. Journal of Occupational Psychology, 79, 101-120.

[24] Martin, C. L. a. N. B. (1996). The Role of Justice Judgments in Explaining the Relationship Between Job Satisfaction and Organizational Commitment. Group and Organization Management 21, 84-104.

[25] Masterson, S. S., Lewis, K., Goldman, B. M., \& Taylor, M. S. (2000). Integrating justice and social exchange : The differing effects of fair procedures and treatment on work relationships. Academy of Management Journal, 43, 738-748.

[26] Mathieu JE, Z. D. (1990). A review and meta-analysis of the antecedents, correlates, and consequences of organizational commitment. Psychological Bulletin 108, 171-194.

[27] McFarlin, D. B. a. P. D. S. (1992). Distributive and Procedural Justice As Predictors of Satisfaction With Personal and Organizational Outcomes. Academy of Management Journal, 35, 626-637.

[28] Messick, D. M. a. K. P. S. (1979). Fairness and Preference. Journal of Experimental Social Psychology, 15, 416-434.

[29] Mowday RT, P. L., Steers RM. . (1982). Employee-organization Linkages. Academic: New York.

[30] Organ DW, R. K. (1995). A meta-analytic review of attitudinal and dispositional predictors of organizational citizenship behavior. Personnel Psychology 48, 775-802.

[31] Randall. (1990). The consequences of organizational commitment: methodological investigation Journal of Organizational Behavior 11, 361-378.

[32] Reichers, A. E. (1985). A review and reconceptualization of organizational commitment. Academy of Management Review, 10, 465-476.

[33] Reichers, A. E. (1986). Conflict and organizational commitments. Journal of Applied Psychology, 71, 508-514.

[34] Super, D., Zelkowitz, R., \& A., T. (1981). career concerns inventory: Adult form 1; . preminary manual New York

[35] Thibaut, J., \& Walker, L. . (1975). Procedural justice: A psychological analysis. hillsadale, NJ: Erlbaum

[36] Walster, E., G. William Walster, and Ellen Berscheid. . (1978). Equity: Theory and Research. Boston: Allyn and Bacon. 